\title{
The Place of Court-Connected Mediation in a Democratic Justice System
}

Nancy A. Welsh

Texas A\&M University School of Law, nwelsh@law.tamu.edu

Follow this and additional works at: https://scholarship.law.tamu.edu/facscholar

Part of the Civil Procedure Commons, and the Dispute Resolution and Arbitration Commons

\section{Recommended Citation}

Nancy A. Welsh, The Place of Court-Connected Mediation in a Democratic Justice System, 5 Cardozo J. Conflict Resol. 117 (2004).

Available at: https://scholarship.law.tamu.edu/facscholar/948

This Article is brought to you for free and open access by Texas A\&M Law Scholarship. It has been accepted for inclusion in Faculty Scholarship by an authorized administrator of Texas A\&M Law Scholarship. For more information, please contact aretteen@law.tamu.edu. 


\title{
THE PLACE OF COURT-CONNECTED MEDIATION IN A DEMOCRATIC JUSTICE SYSTEM
}

\author{
Nancy A. Welsh*
}

A justice system, and the processes located within it, ought to deliver justice. ${ }^{1}$ That seems simple enough. But, of course, delivering justice is never so simple. Justice and the systems that serve it are the creatures of context.

This Article will consider mediation as just one innovation within the much larger evolution of the judicial system of the United States. First, this Article will outline how the values of democratic governance undergird our traditional picture of the American justice system, presumably because the invocation of such values helps the system to deliver something that will be respected by the nation's citizens as "justice." The Article will then highlight particular aspects of the changing picture of the American civil justice system to suggest that today's sprawling and multitiered structure is increasingly disengaged from its democratic roots. Finally, the Article will examine the place of court-connected mediation in this evolution. Is it part of the reinvigoration or further erosion of a democratic justice system?

\section{The Problem of Defining Justice}

Much has been written about the inevitable subjectivity of defining justice. ${ }^{2}$ Reflecting different circumstances, personalities, and cultures, people apply widely varying criteria to determine whether particular outcomes are fair. ${ }^{3}$ Equality, need, generosity,

* Associate Professor of Law, The Dickinson School of Law of The Pennsylvania State University; B.A., magna cum laude, 1979, Allegheny College; J.D., Harvard Law School, 1982. My thanks to Brian Ford for his research assistance.

1 See, e.g., Note, Caroline Harris Crown, The Alternative Dispute Resolution of 1998: Implementing a New Paradigm of Justice, 76 N.Y.U. L. REV. 1768 (2001).

2 See generally Crown, supra note 1.

3 See, e.g., Robert G. Bone, Agreeing to Fair Process: The Problem With Contractarian Theories of Procedural Fairness, 83 B.U. L. REV. 485 (2003) (examining the role of justice in procedural rules). See also Wayne D. Brazil, Court ADR 25 Years After Pound: Have We Found A Better Way?, 18 OHIO ST. J. ON Disp. Resol. 93 (2002) (reviewing court-ordered ADR's role in providing "justice" to parties); see also Robert L. Carter, Oh, Ye of Little 
envy, equity-all of these represent legitimate but very different bases for generating "fair" or "just" outcomes. ${ }^{4}$ Beyond this, people's perceptions of justice seem inevitably affected by self-interest, or an "egocentric bias." Often unconsciously and quite naturally, people define fair outcomes in ways that favor themselves. ${ }^{6}$

Given the difficulty-indeed, the apparent impossibility-of producing outcomes that everyone will immediately embrace as "just," the best that a society may be able to do is to focus upon who will be permitted to decree particular outcomes as just (with the enforcement power of the state to back such decrees) and how these persons will reach their decisions. ${ }^{7}$ Different nations have established strikingly different justice systems, ${ }^{8}$ all nonetheless

(Good) Faith: Questions, Concerns and Commentary on Efforts to Regulate Participant Conduct in Mediations, 2002 J. Disp. Resol. 367 (2002).

4 See, e.g., Nancy A. Welsh, Perceptions of Fairness in Negotiation _ Maro. L. Rev. - (2004) (forthcoming, on file with the author) (describing different criteria that people use in defining substantive justice and variables that affect the selection of such criteria).

5 See Linda Babcock et al., Biased Judgment of Fairness in Bargaining, 85 Ам. EcoN. REV. 1337 (1995).

6 See id. See also Leigh Thompson \& Janice Nadler, Judgmental Biases in Conflict Resolution and How to Overcome Them, in HandBook of Conflict Resolution (Morton Deutsch \& Peter Coleman, eds., 2000).

7 The procedural justice literature is quite helpful regarding this second element and suggests that decisions should be made only after disputants have had an opportunity to be heard and the decision-maker has considered their views or arguments while treating the disputants in an even-handed and dignified manner. See Nancy A. Welsh, Making Deals in Court-Connected Mediation: What's Justice Got To Do With It?, 79 WASH. U. L.Q. 787, $817-30$ (2001) (describing the effects and characteristics of procedural justice, as well as theories explaining those effects).

8 The United States, for example, has a justice system that is characterized by substantial party control. The litigants define the issues, determine what discovery to conduct, raise the issues that will be tested through motion practice, and ultimately control the presentation of the evidence to the judge or jury. Attorneys' primary loyalty is to their clients, and attorneys advocate on their clients' behalf. This is the system that Civil Procedure and Advocacy professors present to American law students. In many other countries, meanwhile, parties' control over their cases is much more restricted. Judges, not litigants or their attorneys, determine the issues that will be explored, the discovery that will be conducted, the witnesses who will be called, and the questions that the witnesses will answer. The parties' testimony is neither sought nor trusted, and the attorneys represent "independent organ[s] of the administration of justice. . . mean[ing] independence from the client as well as from the state." David Luban, Lawyers and Justice: An Ethical Study 67103 (1988). See also Oscar Chase, Legal Processes and National Culture, 5 CARdozo J. INTL. \& Comp. L. 1 (1997); John H. Langbein, Cultural Chauvinism in Comparative Law, 5 Cardozo J. InTL. \& Comp. L. 41 (1997); John H. Langbein, The German Advantage in Civil Procedure, 52 U. CHI. L. REv. 823 (1985). 
aimed at the production of outcomes that are likely to be trusted by citizens as sufficiently just. ${ }^{9}$

Inevitably, a society's values regarding the relationship between citizens and governmental authority influence the shape of its justice system, particularly the criteria for selecting decisionmakers whose decisions will be enforced by the state and the procedures that those decision-makers will use. Democratic systems of governance are characterized by procedures and structures designed to hold "rulers . . . accountable for their actions in a public realm by citizens, acting independently or through the competition and cooperation of their elected representatives." 10 In a democracy such as the United States, the rulers-including the decisionmakers-must submit to mechanisms that make them accountable to "the people," and they draw legitimacy from such accountability. ${ }^{11}$ The transparency of this accountability affects democratic citizens' ability to trust that their decision-makers will deliver fair outcomes. It should not be surprising, therefore, that even though American courts are often described as the least democratic branch of government, their fundamental democratic pedigree is revealed in the mechanisms established for the appointment of judges and juries, the public nature of trials, the requirement of written opinions and the availability of appeal.

The most transparent example of structuring American courts to maximize accountability to "the people" involves the peculiarly American institution of the civil jury. Historically, the colonists viewed juries as the "guardians of local community values against outsider judges appointed by the royal governor" and "as bulwarks of integrity against corrupt public officials." 12 Leaders of the

9 See, e.g., Austin Sarat \& Jonathan Simon, Beyond Legal Realism?: Cultural Analysis, Cultural Studies, and the Situation of Legal Scholarship, 13 Y ALE J.L. \& Human. 3 (2001) (examining cultural differences and their effects on legal analysis). See also New Zealand Modernizes Arbitration Act, 8 World ARb. \& Mediation Rep. 127 (1997) (discussing New Zealand's legal approach in reforming its arbitral system to maximize benefits of arbitrations). See also Tom Arnold, Why is ADR the Answer?, 15 No. 7 Computer Law 13 (1998) (reviewing the use of ADR by other countries and its advantages over litigation).

10 Philippe C. Schmitter \& Terry Lynn Karl, What Democracy Is. . . and Is Not, The Global Resurgence of Democracy 49, 49-50 (Larry Diamond \& Marc F. Plattner eds., 1993) cited in Richard C. Reuben, Democracy and Dispute Resolution: The Problem with Arbitration, 67 LAW \& Contemp. Probs. (2004) (forthcoming, on file with author).

11 See generally Michael R. Dimino, Pay No Attention to that Man Behind the Robe: Judicial Elections, The First Amendment, and Judges as Politicians, 21 YAlE L. \& POL'Y REv. 301 (2003) (describing the benefits of a democratic system in which judges can be selected or appointed in part as representatives of the people).

12 Stephen N. Subrin et al., Civil Procedure: Doctrine, Practice and ConTEXT 434 (2000). 
movement for American independence complained mightily about British attempts to reduce colonists' access to decision-making by juries. ${ }^{13}$ Indeed, the importance of the right to civil jury trial emerged in state legislatures' debates regarding ratification of the Constitution. The Seventh Amendment ultimately provided that "[I]n suits at common law, where the amount in controversy exceeds twenty dollars, the right to trial by jury shall be preserved. . . By 1835, Alexis de Toqueville proclaimed the American jury as:

one form of the sovereignty of the people... The jury, and more especially the civil jury, serves to communicate the spirit of the judges to the minds of all the citizens; and this spirit, with the habits which attend it, is the soundest preparation for free institutions. . . It invests each citizen with a kind of magistracy; it makes them all feel the duties which they are bound to discharge towards society and the part which they take in its government. ${ }^{14}$

A more contemporary commentator has observed: "More than when they vote, or pay taxes, or attend a parade, they [jurors] are realizing the democratic vision that still sustains our nation: They are governing themselves." 15

The selection of federal and state judges is also grounded in the democratic presumption of accountability to "the people."16 Federal judges are nominated by an elected President and installed only after elected U.S. Senators have approved them. ${ }^{17}$ State judges, similarly, are selected by elected representatives "of the

13 See id. Juries were mentioned in the Declaration of Independence. Once the colonies had achieved independence and American judges headed various courts, however, some of the new nation's leaders feared that juries "were thwarting creditors from collecting on their debts and jeopardizing [America's] economic stability." Id. As a result, they sought to reduce the influence of civil juries and succeeded in blocking any mention of them in the Constitution drafted at the Constitutional Convention. See id.

14 Alexis de Tocqueville, Democracy in America, Pt. II, Ch. B (1835).

15 Stephen J. Adler, Trial and Error in the American Courtroom 242 (1994). See Valerie P. Hans \& Neil. Vidmar, Judging the Jury $247-49$ (1986) (the jury is an important symbol [of democracy] that helps to confer legitimacy to law. . Not only does the jury system allow the people to contribute to the legal system, but the legal system, through the jury, contributes to the education of the people).

16 See generally Dimino, supra note 11.

17 Of course, there are occasional and unfortunate exceptions to this process. For example, President George W. Bush recently appointed two judges to the federal bench while the U.S. Senate was in recess. See, e.g., Charles Hurt, Daschle Threatens to Block All Bush Judicial Nominees, WASH. TIMEs, Mar. 27, 2004, available at http://www.washington times.com/national/20040326-112701-8188r.htm (last visited Apr. 2, 2004). 
people"-or must face direct election and re-election by citizens. ${ }^{18}$ Though both appointment and election have potential disadvantages, ${ }^{19}$ such approaches to selection at least acknowledge citizens' appropriate role in selecting the decision-makers whose rulings will be enforced by the state. This form of selection also assures some level of accountability by judges to the citizens. Indeed, perhaps because many states' judges must return regularly to the citizens for re-election, these courts are more likely than federal courts to include citizen representatives in their planning processes and to focus on the need to provide "user-oriented" access. ${ }^{20}$

Traditionally, then, when we have described the American justice system, we have drawn a clear relationship between democratic governance and the identification of the decision-makers whose determinations of elusive "justice" will be enforced as pronouncements of the state. This picture assumes the appropriateness of accountability to "the people." The traditional picture, however, no longer sufficiently represents the reality of the U.S. justice system. It may even misrepresent the bulk of that system and its level of accountability to a democratic citizenry.

\section{Drifting from Democratic Accountability as THE SAFEgUARD OF "Justice"}

For the past several decades, nearly every democratic institution has come under increasingly injurious attack as inefficient, unable to fulfill its mission, and often inept. ${ }^{21}$ The public justice system has been no exception. ${ }^{22}$ Critics have derided the courts as

18 For a comparative analysis of different means of selecting state and federal judges, see Alain A Levasseur, Legitimacy of Judges, 50 Aм. J. CoMP. L. 43 (2002).

19 See Judith Resnik, Uncle Sam Modernizes his Justice: Inventing the Federal District Courts of the Twentieth Century for the District of Columbia and the Nation, 90 GEO. L. J. 607,662 n. 244, 669 (2002) (raising concerns regarding the effect of these processes on judicial independence and observing that "money and politics can play large roles in who can become a judge.").

20 See Judith Resnik, Trial as Error, Jurisdiction as Injury, Transforming the Meaning of Article III, 113 HaRv. L. Rev. 924, 1022-24 n. 381, n. 385 (2000).

21 Public schools, Amtrak, and the United States Post Office are among the most obvious examples.

22 See, e.g., Karen L. Kennard, Comment, The Victim's Veto: A Way to Increase Victim Impact on Criminal Case Disposition, 77 CAL. L. REv. 417, 417 (1998). "Victim withdrawal from the criminal justice process creates a public impression that the system is inefficient and unresponsive, and thus, exponentially increases the likelihood that more victims will be deterred from reporting crimes and testifying in court." Id. 
"dysfunctional."23 Its juries who are supposed to represent the citizenry are marred by "rogue" or "runaway" tendencies. ${ }^{24}$ Judges are "arbitrary." 25 Indeed, what is curious is that those closest to the courts-attorneys and judges-have been some of the most consistent and vociferous critics of the justice system. ${ }^{26}$ Research indicates, for example, that in meetings with clients, attorneys often paint a bleak picture of the courts, emphasizing the likelihood of ill-informed, disrespectful and arbitrary decision-making. ${ }^{27}$

Judges, meanwhile, have expressed very serious "postmodern" angst about their role. ${ }^{28}$ Recently, one Pennsylvania trial court judge wrote: " $[\mathrm{H}]$ aving watched the process as a judge for nearly 20 years, it seems to me that the legal system can produce stability, predictability, recompense, retribution and perhaps many other things. What we cannot produce is true justice." 29 Professor Judith Resnik has written extensively about the federal courts' evolving composition and self-understanding, concluding that, "the federal judiciary has adopted an anti-adjudication and pro-settlement agenda," which includes a diminution in the role of traditional judges and the embrace of a variety of "new" quasi-judges or judi-

23 John R. Thomas, Formalism at the Federal Circuit, 52 AM. U. L. REv. 771 (2003).

24 See David E. Rovella, 1998 Jury Outlook Survey: Poll Elicits Fear of Rogue Jury, NAT'L. L.J., Nov. 2, 1998, at A25.

25 Stephen N. Subrin, Uniformity in Procedural Rules and the Attributes of a Sound Procedural System: The Case for Presumptive Limits, 49 ALA. L. REv. 79 (1997). "It might well be maintained, indeed, that as between arbitrary action of the law in nearly all cases because of the complexity of procedure, and arbitrary action of the judge in some cases, the latter would be preferable." Id.

26 See Jean Sternlight, ADR is Here: Preliminary Reflections on Where It Fits in a System of Justice, 3 Nev. L. J. 289, 297 (2003).

27 See Austin Sarat \& William L.F. Felstiner, Lawyers and Legal Consciousness: Law Talk in the Divorce Lawyer's Office, 98 Y ALE L. J. 1663, 1676-82 (1989) (recording divorce lawyers' discussions with clients, advising against too much open communication and urging clients to adopt an affected poise).

28 Professor Judith Resnik has written:

[F]ederal judges begin to appear (oddly) aligned with movements denominated "postmodern." Federal judges may press for settlement because they themselves doubt their own capacities to find information sufficient to call "fact" and are painfully aware of the plasticity of "law." Federal judges act as if they believe that stories dissolve in endless variations, none of which justify the imposition of state power. From this vantage point, federal judges can be understood as encouraging disputants to do as they want, for in these private accords lies as much-or as little-as what adjudication can offer.

Resnick, supra note 20, at 1003 (emphasis added).

29 John M. Cleland, A Place for Counselors and Peacemakers, 26 PA. LAw. 36, 37 (2004). See also Resnik, supra note 20, at 926 (describing a trial judge who "equated going to trial with failure" and the frequency of the phrase "a bad settlement is almost always better than a good trial" in judicial opinions) (emphasis added). 
cial adjuncts. ${ }^{30}$ In the process, the "markers of difference [between traditional judges and other fact-finders] have diminished, while enthusiasm for delegation has grown." ${ }^{31}$

This evolution may, as Professor Resnik suggests, represent the judicial system's inventive (or desperate) response to the nation's growing demand for adjudicative services accompanied by politicians' refusal to allocate the funds needed for a significantly expanded judiciary. ${ }^{32}$ The judicial system's evolution may even be anticipated by organizational theories that predict that overwhelmed organizations will react by "increasing the numbers and kinds of providers, delegating duties, routinizing processes, and reconfiguring the work." 33 Indeed, social psychological theories may have predicted the judicial system's recent tendency to mirror the growth and bureaucratization of the other two branches of government and to spawn more tiers of hierarchy. ${ }^{34}$

Despite the explanations, however:

in reinventing the role of the judge, [the federal judiciary] has also succeeded in undermining its singular claim to constitutional protection. . . Judges have, through their practices and doctrine, not only made plain the many facets of the role of judge, (judge as settler, judge as negotiator, judge as manager, judge as dealmaker) but also have so deconstructed judging that it is at risk of being undermined as a politically or legally viable concept. ${ }^{35}$

30 See Resnik, supra note 20, at 995.

31 Resnik, supra note 19, at 641.

32 See Resnik, supra note 20, at 998 . The extensive use of non-life-tenured judges also permits federal courts to work around the frequent and long political delays associated with the appointment and approval of federal judges. Professor Resnik aptly notes:

At least in some respects, rather than having been transformed into a co-equal branch of government, the judiciary at times seems more like an ordinary agency, petitioning for attention and hoping to achieve the budgetary goals it seeks. Recall the image of a sprawling. multi-tiered judiciary, populated by 2000 judges and 30,000 staff. The federal judiciary, a bureaucratic institution, is heavily dependent on Congress for resources.

Id. at 1011. See also Resnik, supra note 19, at 621.

33 Resnik, supra note 19 , at 659.

34 See, e.g., id. at 619-20, 659-60, n. 235 and accompanying text.

35 Resnik also notes that:

[a] different kind of concern emerges about the deconstructive role of federal judges if one is intent on federal judicial supremacy but worried about how to maintain it. By encouraging a host of ADR providers, judges (who used to have a monopoly on the provision of judicial services) have helped to launch their competitors and now may have to jockey for what they deem to be the "good cases."

Resnik, supra note 20, at 1003 n. 316. 
The courts' expressions of self-doubt, though they evidence a somewhat attractive humility, also hint at a worrisome insecurity about publicly-elected and publicly-appointed judges' unique ability to declare justice in a democratic nation. ${ }^{36}$ Furthermore, the courts' lack of self-esteem (some might even say self-loathing) has paved the way for other, less introspective and less accountable players to assume the role of decision-makers. ${ }^{37}$

\section{A. Delegation and Deference to Adjudication by Administrative Agencies}

Employees of administrative agencies today provide the first tier of adjudication for many, many disputes involving American citizens and their government. American courts' reliance upon and deference to the jurisdiction and decisions of this "hidden judiciary" 38 represents this Article's first example of disengaging the real judicial system of the United States from meaningful democratic accountability.

In 1934, proponents of the New Deal justified administrative agencies' assumption of adjudicative powers by pointing out the inadequacies of the courts: "the condition of our court dockets, the congestion of court calendars, the interminable delays and innumerable reverses on technical judicial grounds," 39 and a conservative judiciary's hostility to needed governmental reforms. ${ }^{40}$

36 See Resnik, note 20, at 926 . "Since the country's founding, the federal courts have been identified as an important participant in national governance." Id.

37 This Article will not criticize the rise of court adjuncts whose role is explicitly defined as assisting, rather than replacing, judges. The United States has a long history of such judicial assistants (e.g., original magistrate judges, special masters, United States commissioners). See, e.g., Resnik, supra note 20 , at 986-89.

38 Thomas C. Mans, Selecting the 'Hidden Judiciary': How the Merit Process Works in Choosing Administrative Law Judges (Part I), 63 Judicature 60 (1979).

39 A.B.A. Special Committee on Administrative Law, Report of the Committee, 1934 A.B.A. ANN. REP. 151 (statement of Charles N. Goodwin), cited in George B. Shepherd, Fierce Compromise: The Administrative Procedure Act Emerges from New Deal Politics, 90 Nw. U. L. Rev. 1557, 1574 (1996).

40 Many New Deal advocates viewed judges of the time as conservative and hostile to the interests of those being served by New Deal agencies. See Resnik, supra note 19, at 635 (noting that "some progressives saw agency decision-making as a welcome escape from the federal courts, perceived as unfriendly to small claimants and specially tied to corporate interests"); see also Shepherd, supra note 39, at 1574 (describing concerns of those opposed to a proposal to establish a specialized administrative court, as a substitute for administrative tribunals).

See also Stephen R. Alton: 
Initially, the Supreme Court objected to legislative and executive attempts to usurp the courts' role, and even as recently as 1982, ruled that Congress had gone too far in the powers granted to bankruptcy judges. ${ }^{41}$

By 1986, however, a majority of the Supreme Court had adopted the anti-court sentiments of New Deal proponents. In Commodity Futures Trading Commission v. Schor, ${ }^{42}$ the Supreme Court proclaimed a flexible balancing test to determine the constitutionality of administrative adjudication of claims that normally would have been heard and decided in the courts. ${ }^{43}$ The majority observed admiringly that the administrative procedure at issue in the case represented an "inexpensive and expeditious' alternative to existing fora available to aggrieved customers, namely, the courts and arbitration[;]" 44 "an agency's expertise is superior to that of a court" 45 when dealing with legislation that the agency is responsible for enforcing, ${ }^{46}$ and the courts should avoid "unduly constrict[ing] Congress' ability to take needed and innovative action. . "47 Not surprisingly, the majority found that the balancing test favored agency adjudication. ${ }^{48}$

The Court 'cannot permanently be used as a conservative veto power,' Jackson proclaimed. Government by litigation was inefficient causing delay and uncertainty. Jackson opined that the judges' 'almost oriental devotion to precedent' obviated their 'need to reason' and restricted the actions not only of the legislative and the executive branches, but of the courts themselves. The United States' 'complicated governmental system,' steeped in federalism, required compromise and understanding from all sides in order to solve 'basic problems arising out of the depression and out of troubled industrial relations,' but 'the Courts have lately been closing the ways to political compromise.' The Assistant Attorney General concluded by declaring that Roosevelt sought 'in his policy and in his Court proposal to open the highway to economic and social peace' and by warning that 'the closed road' may mean a rough detour.

Loyal Lieutenant, Able Advocate: The Role of Robert H. Jackson in Franklin D. Roosevelt's Battle with the Supreme Court, 5 WM. \& MARY BILL RTS. J. 527, $590-91$ (1997).

41 See N. Pipeline Constr. Co. v. Marathon Pipe Line Co., 458 U.S. 50, 60 (1982). "In sum, our Constitution unambiguously enunciates a fundamental principle-that the 'judicial Power of the United States' must be reposed in an independent Judiciary. It commands that the independence of the Judiciary must be jealously guarded, and it provides clear institutional protections for that independence." Id.

42478 U.S. 833 (1986).

43 The issue was whether an administrative agency had the jurisdiction to hear and adjudicate common law counterclaims. See id.

44 Id. at 836.

45 Id. at 845 .

46 See id. at 845.

47 Id. at 851.

48 See id. at 858. 
An obviously upset dissenting Justice Brennan expressed tremendous frustration with the majority's "abdication to claims of legislative convenience." ${ }^{49}$ Joined by Justice Marshall, Justice Brennan highlighted the importance of protecting accountability in a democratic system of governance:

The choices we discern as having been made in the Constitutional Convention impose burdens on governmental processes that often seem clumsy, inefficient, even unworkable, but those hard choices were consciously made by men who had lived under a form of government that permitted arbitrary governmental acts to go unchecked. . . With all the obvious flaws of delay [and] untidiness. . . we have not yet found a better way to preserve freedom than by making the exercise of power subject to the carefully crafted restraints spelled out in the Constitution. ${ }^{50}$

Justice Brennan further observed, "Convenience and efficiency are not the primary objectives - or the hallmarks-of democratic government. . " 51

Partly as a result of courts' doctrinal and philosophical choices like the one demonstrated in Commodity Futures, which seem to "make an ever-larger path for Congress to create [non-traditional] judgeships[,]" 52 federal and state agencies today represent a vast and parallel "set of courts, with a specialized focus frequently involving claims against the government." 53 There are many more non-elected, non-legislatively-appointed judges located within federal agencies than there are traditional federal judges. In 2000, for example, there were about 829 Article III judges (i.e., 650 federal district court judges, 170 judges serving on federal courts of appeal, and 9 Supreme Court justices). ${ }^{54}$ Meanwhile, federal agencies housed more than 1,400 semi-independent administrative law judges along with nearly 3,000 agency employees given titles, such as "hearing officers," "presiding officers," or "hearing examiners," responsible for "fulfilling judge-like roles but doing so outside the

\footnotetext{
49 Id. at 863 .

50 Id. at 864 .

51 Id. at 864 .

52 Resnik, supra note 19, at 626.

53 Owen M. Fiss \& Judith Resnik, Adjudication and Its Alternatives: An In. troduction to Procedure 37 (2003).

54 See $i d$. at 33 . In addition, in 2000 , "about 315 bankruptcy judges and 450 magistrate judges served for renewable terms." Id.
} 
confines" 55 of the Administrative Procedure Act (the "APA"). The number of cases handled by agency adjudicators dramatically exceeds those filed in courts. In the late 1990's, for example, the Social Security Administration handled more than 500,000 cases per year, while there were about 260,000 civil filings in the federal courts. ${ }^{56}$

Many have raised concerns regarding the relationship between administrative adjudicators and the agencies that select them, employ them and then turn to them for decisions in disputed cases. ${ }^{57}$ To reduce agencies' ability to influence individual Administrative Law Judges ("ALJs"), the APA provides certain salary and employment protections; ${ }^{58}$ ALJs also may be disqualified on the basis of personal bias. ${ }^{59}$ But most ALJs remain embedded within agencies, and structural bias is rarely viewed as a sufficient basis for disqualification or vacatur of an ALJ's decision. ${ }^{60}$ The concerns are even stronger for the hearing officers, presiding officers and hearing examiners described supra. They do not come within the protections of the APA, often are expected to serve multiple roles (e.g., regulator and hearing examiner), and are given none of the markers of judicial prestige. These conditions suggest strongly that many administrative adjudicators will feel more accountable to the agencies and their current interpretations of their missions, than to "the people." Perhaps predictably, these largely-unprotected adju-

55 Id. at 40 (observing that these adjudicators represent the "hidden judiciary" and that the number of hearing officers in different federal agencies varies dramatically, with one full-time judicial officer in the United State Post Office in 2001 and 1,100 located in the Social Security Administration); see also Resnik, "Uncle Sam Modernizes His Justice": Inventing the Federal District Courts of the Twentieth Century for the District of Columbia and the Nation, 90 GEO. L. J. 607, 620 (2002).

56 Fiss \& RESNIK, supra note 53, at 40.

57 See Commodity Futures Trading Commission v. Schor, 478 U.S. 833, 861 (1986) (dissenting opinion of J. Brennan) (quoting The Federalist No. 78 (Alexander Hamilton), regarding the "danger of an improper complaisance to the branch which possessed it"). See also Gerald Ruth, Unification of the Administrative Adjudicatory Process: An Emerging Framework to Increase "Judicialization" in Pennsylvania, 5 WIDENER J. PuB. L. 297, 321-24 (1996) (describing several states' decision to establish central panel systems to increase an ALJs' sense of independence from agencies).

58 See 5 U.S.C. $\$ \S 554,5362,4301$ (providing for separation of adjudicative, investigative and prosecuting functions, removing agency control over tenure and compensation decisions, and exempting ALJs from certain performance ratings); Alfred C. AMAN, JR. \& William T. Mayton, Administrative Law, 240-42 (2d ed. 2001) (observing that the APA seeks to promote ALJ's neutrality and that such neutrality would be aided by creating a "unified corps of ALJs and a central panel system" that would be separate from individual agencies).

59 See AmAn \& Mayton, supra note 58, at 249-53.

60 See id. at 249. 
dicators are the "judges" that agencies are adding in greater numbers. ${ }^{61}$

The justice provided by these non-democratically-selected judges is supposed to be safeguarded by citizens' right to seek appellate review before a traditional court. ${ }^{62}$ The courts, however, exercise an extraordinarily light supervisory touch over their administrative delegates. First, the courts generally limit their review to the record as developed by administrative courts, and may even be satisfied with the findings of fact and reasoning contained in administrative judges' opinions. ${ }^{63}$ Second, the courts grant great deference ${ }^{64}$ to the decisions of agencies' judges, generally not overturning them unless they are proven to be "arbitrary, capricious or an abuse of discretion," 65 represent a "clear error" 66 or violate other, even more stringent standards.

Administrative agencies' usurpation of the judicial role is important as a matter of separation of powers and appropriate institutional relations among the various branches of government. But

61 See Resnik, supra note 19, at 662-63. See also Jeffrey S. Lubbers, APA-Adjudication: Is the Quest for Uniformity Faltering?, 10 ADMin. L. J. AM. U. 65, 70-71 (1996) (regarding non-APA judges in Departments of Justice, Agriculture and Defense); Ronnie A. Yoder, Retrospectives and Prospectives on ALJ Priorities - A Report in Progress, delivered at the Federal Administrative Law Judges Seminar at Virginia Beach, Va. (Sept. 15, 1998) (on file with the author).

62 See Resnik, supra note 19, at 638-40, 668; see also Richard Fallon, Jr., Of Legislative Courts, Administrative Agencies, and Article III, 101 Harv. L. Rev. 915, 923-33 (1988) (summarizing case law permitting agency adjudication and relying upon judicial review as a safeguard).

63 See Crowell v. Benson, 285 U.S. 22, 63-65 (1932) (providing for review based on record as developed by administrative court); AMAN \& MAYTON, supra note 58, at 256-59 (describing record required to survive judicial review of informal agency action).

64 See Kenneth W. Starr, Judicial Review in the Post-Chevron Era, 3 YAle J. ON REg. 283 (1986).

Affording deference to any agency's legal analysis, however, seems facially contrary to the fundamental principle, incorporated in Chief Justice John Marshall's broad dictum in Marbury v. Madison, that "[i]t is emphatically the duty of the judicial department to say what the law is." Judicial deference to agencies' statutory interpretations thus constitutes a continuing source of tension for judges because it necessarily means that an agency of the executive branch, to a greater or lesser degree, is displacing the judiciary in its traditional and jealously guarded law-declaring function. Largely because of this tension between the judiciary's law-declaring function and the need to defer to congressional delegation, application of the deference doctrine in the federal courts has been rather erratic.

Id.

655 U.S.C.S. $\S 706(2)$ (B) (2004).

66 See generally Patricia Wald, Some Thoughts on Beginnings and Ends: Court of Appeals Review of Administrative Law Judges' Findings and Opinions, 67 WAsH. U. L.Q. 661 (1989) (describing the critical role that fact-finding plays and the great deference accorded to administrative law judges' findings, resulting in significant and growing power). 
the rise of decision-making by those who have neither been elected nor appointed by elected officials (and who may be understood as only "quasi-independent" of home agencies) also should raise concerns regarding the dilution of our justice system's relationship to democratic governance as a safeguard of "justice." The commitment to justice as determined by representatives "of the people" is giving way to resolution by those who are more likely to accommodate the structure, norms and needs of one set of the players-the institutional, repeat players-involved in disputes.

\section{B. The Embrace of and Deference to Decision-Making by Arbitrators}

More recently, the courts have embraced arbitrators as another set of decision makers to whom the courts may delegate adjudicative responsibilities. ${ }^{67}$ Historically, merchants turned to arbitration for cost effective and efficient resolution that would be consistent with industry norms. ${ }^{68}$ Over the years, however, courts have praised the process for its "simplicity, informality, and expedition" 69 and expanded its permissible use to include the resolution of statutory claims and disputes involving employers and employees, consumer companies and individual consumers, securities dealers and individual investors, and franchisors and franchisees. Indeed, the Supreme Court has established a preference for arbitration, finding that "questions of arbitrability must be addressed with a healthy regard for the federal policy favoring arbitration. . . [A]ny doubts concerning the scope of arbitrable issues should be resolved in favor of arbitration." ${ }^{70}$ Today, large numbers of dis-

67 See A. Leo Levin, Reducing Court Costs and Delay: Court-Annexed Arbitration, 16 U. Mich. J.L. Reform 537 (1983).

68 See Thomas E. Carbonneau, The Story of Arbitration Law, 14, No. 6 World ARB. \& MEDiATION. REP. 162, 163 (2003) (noting that the "many different chapters to the story of arbitration" include "the theme of contract freedom that ... challenges the authority of the established social hierarchy in elaborating essential norms[,]" as well as the need for American society to "secure a measure of workable adjudicatory justice for its citizens" and respond to "the social thirst for fair and rational ordering").

69 Mitsubishi Motors Corp. v. Soler Chrysler Plymouth, 473 U.S. 614 (1985).

70 Id. at 626 (quoting Moses H. Cone Mem'l Hosp. v. Mercury Constr. Corp., 460 U.S. 1, 24-25 (1983)). But see Richard Reuben, First Options, Consent to Arbitration, and the Demise of Separability: Restoring Access to Justice for Contracts with Arbitration Provisions, 56 SMU L. REv. 819, 830, 860-65 (2003) (discerning a hint in recent decisions of the Supreme Court that it may be demonstrating less deference toward arbitration and the achievement of judicial efficiency after "a burst of judicial exuberance"). 
putes are resolved through arbitration. ${ }^{71}$ In several recent decisions that have upheld mandatory arbitration clauses, a majority of the Supreme Court has once again displayed a rather remarkable lack of self-respect for the unique role of the courts, as democratic institutions, to declare justice. ${ }^{72}$ In Mitsubishi, for example, the Court observed:

[W]e are well past the time when judicial suspicion of the desirability of arbitration of the competence of arbitral tribunals inhibited the development of arbitration as an alternative means of dispute resolution. . . By agreeing to arbitrate a statutory claim, a party does not forego the substantive rights afforded by the statute; it only submits to their resolution in an arbitral, rather than a judicial, forum. ${ }^{73}$

In Gilmer, the Court brusquely rejected "generalized attacks on arbitration" as "far out of step with our current strong endorsement of the federal statute favoring this method of resolving disputes." 74 Professor Tom Carbonneau has written recently that "[i]n recent case law, the right [to arbitrate] may have been transformed into an obligation to arbitrate." 75

Similar to administrative adjudication, arbitration is often sought or required by the organizations and corporations that anticipate being repeat players in litigation. As arbitration has expanded into areas marked by unequal bargaining relationships,

71 See Cameron Sabin, The Adjudicatory Boat Without a Keel: Private Arbitration and the Need for Public Oversight of Arbitrators, 87 Iowa L. Rev. 1337, 1339-40 (2002) (reporting that between 1995 and 1999, AAA's caseload grew from 55,800 to 136,673 , while JAMS' caseload grew "by more than 2,300 percent from 1987 to 1993 . . averaging 1,200 cases a month in 1993").

72 See Reuben, supra note 70 , at 860-65. Reuben also observes that when litigants expect access to a courtroom and instead, under the doctrine of separability, are "thrust into a forum in which standard contract defenses have no legal force[,]" and so litigants' trust in the courts and rule of law may suffer. Id. at 848 .

73 Mitsubishi Motors Corp., supra note 69, at 626-27.

74 Gilmer v. Interstate/Johnson Lane Corp., 500 U.S. 20, 30 (1991) (quoting Rodriguez de Quijas v. Shearson/ American Express, Inc. 490 U.S. 477, 481 (1989)).

75 Carbonneau, supra note, at 68 (emphasis added). Professor Carbonneau also argues:

The rise of arbitration demonstrates the inability of courts to remain functional when proceedings are dominated by adversarial legal representation and an unbending standard of due process. . .In different ways and to different degrees. . .arbitration and mediation cure the failings of the law and the judicial process. The growing success of these procedures argues persuasively for limiting the State's jurisdictional authority to matters of criminal liability and to the resolution of divisive political issues. . Arbitration and mediation not only "deconstruct" the law, but they also provide for "reconstruction" by acting as substitute processes for dispute resolution.

Id. See also Richard Reuben, Constitutional Gravity: A Unitary Theory of Alternative Dispute Resolution and Public Civil Justice, 47 UCLA L. Rev. 949 (2000). 
commentators have increasingly raised concerns regarding the structural bias arising out of arbitrators' and arbitral organizations' financial reliance upon these institutional, repeat users of arbitration services. ${ }^{76}$ In California, such concerns have resulted in new, strict ethics standards requiring arbitrators to make individual disclosures regarding information that might indicate personal favoritism towards repeat players, as well as potential bias on the part of the provider organizations with which the arbitrators are associated. ${ }^{77}$

The courts' standard of review to assure the justice provided by arbitrators' decisions, meanwhile, is even more limited than that available for reviewing the decisions of administrative judges. The Federal Arbitration Act ("FAA") permits courts to vacate arbitral awards only on the grounds of corruption or if the arbitrators have engaged in extraordinary adjudicatory unfairness or exceeded their powers. ${ }^{78}$ Courts have also developed three common law grounds for vacatur-manifest disregard of the law, arbitrary or capricious or irrational, violation of public policy-but "[s]omewhat paradoxically, the elaboration of [these] additional grounds for review in the case law has not created a greater likelihood of vacatur." 79 For example, in order to demonstrate manifest disregard of the law, an arbitral award must display "more than an error or misunderstanding with respect to the law. . . The error must have been obvious and capable of being readily and instantly perceived by the average person qualified to serve as an arbitrator." 80 Further, in order to show "disregard," the party seeking vacatur must be able to show that "the arbitrator appreciate[d] the existence of a clearly governing legal principle, but decide[d] to ignore or pay attention to it." 81 Making this showing is made almost laughably difficult by the FAA's and courts' failure to require arbitrators to explain the

76 See Jay Folberg, Arbitration Ethics: Winds of Reform Blowing from the West?, Disp. RESOL. MAG., Fall 2002, at 5 (describing reasons underlying establishment of new disclosure requirements for arbitrators in California).

77 See id. at 6-8.

78 See Federal Arbitration Act, 9 U.S.C. $\S 10$.

79 Thomas E. Carbonneau, The Law and Practice of Arbitration 297 (2004). See Baravati v. Josephthal, Lyon \& Ross, Inc., 28 F.3d 704, 706 (7th Cir. 1994) ("Th[e] formula [for manifest disregard of the law] is dictum, as no one has found a case where, had it not been intoned, the result would have been different.").

80 Merrill, Lynch, Pierce, Fenner \& Smith Inc. v. Bobker, 808 F.2d 930, 933 (2d Cir. 1986).

81 Id. 
reasons for their awards. ${ }^{82}$ Once again, the courts' enthusiasm for delegating decision-making to other adjudicators has been accompanied by a level of supervision that "take[s] on an air of unreality." 83

As evidenced by repeat players' dominance in the selection of arbitrators and the near-meaninglessness of the judicial review of arbitral decisions, the courts seem to be giving no thought to the need to make adjuncts of the judicial system accountable in some way to the people of a democratic nation. ${ }^{84}$ In their zeal to divert cases to arbitrators for decision-making, the courts are further distancing the judicial system from its democratic roots.

\section{The Marginalization of the Jury in Civil Litigation}

Meanwhile, of course, the peculiarly democratic institution of the civil jury has been steadily marginalized until it is now in a near-iconic state.$^{85}$ Historically, courts permitted cases to go to juries for fact-finding as long as the record contained evidence of "some non-frivolous dispute about the existence or interpretation

82 See Allan Scott Rau et al., Processes of Dispute Resolution: The Role of LAWYERS 745 (3rd ed. 2002) (noting that "the obvious less of innumerable commercial arbitration cases is that lack of a reasoned opinion will help to insulate an award from judicial scrutiny."). See also Stroh Container Co. v. Delphi Indus., Inc., 783 F.2d 743 (8th Cir. 1986) (holding that because the award presented "only a cursory discussion of what the arbitrators considered to be the key points underlying the award[,]" the court concluded that "[i]t cannot be said that it clearly appears that the arbitrators identified applicable law and proceeded to reach a contrary position in spite of it."); Perini Corp. v. Greate Bay Hotel \& Casino Inc., 129 N.J. 479 (N.J. 1992) (confirming arbitral award of \$14 million accompanied by a one-sentence explanation, where a concurring justice observed, "for all we know, the arbitrators concluded that the sun rises in the west, the earth is flat, and damages have nothing to do with the intentions of the parties or the foreseeability of the consequences of a breach.").

$83 \mathrm{Id}$. at 745. Courts have even found a way to strengthen the deference that should be shown to the awards of court-connected arbitrators in "non-binding" arbitration programs. Increasingly, parties who have participated in non-binding arbitration may be sanctioned if they request a trial de novo and fail to improve sufficiently upon the "advisory" arbitral award. These disincentives become more than a little worrisome when one factors in the reality that these arbitral proceedings are quick, and courts rarely try to match arbitrators' substantive expertise with cases.

84 See Reuben, supra note 70 , at $121-22$ (finding that there is little accountability in arbitration; also examining the extent to which arbitration is consistent with other democratic values such as participation, transparency, rationality, equality, due process, and personal autonomy and dignity).

85 See generally Laura Gaston Dooley, Our Juries, Our Selves: The Power, Perception, and Politics of the Civil Jury, 80 CoRnell L. Rev. 325 (1995). 
of a fact[.]" reasonable jury's response." 87 That stance changed after 1986, at approximately the same time that the number of trials in federal courts was reaching its peak. ${ }^{88}$ In a series of three cases, the Supreme Court effectively transformed summary judgment from "a disfavored procedural shortcut" 89 into a potent tool for winnowing the number of cases reaching juries for disposition. The Court accomplished this by reducing the burden borne by those making summary judgment motions (usually defendants) ${ }^{90}$ and by authorizing judges to be more expansive in "determining what issues merit[ed] presentation" 91 to jurors. In Anderson v. Liberty Lobby, Inc. ${ }^{92}$ the Supreme Court directed judges to determine whether "the evidence [wa]s such that a reasonable jury could return a verdict for the nonmoving party." ${ }^{93}$ Matsushita Electric Industrial Co. v. Zenith Radio Corp.${ }^{94}$ permitted a trial judge to grant summary judgment if, despite the existence of evidence to support the nonmovant's arguments regarding a genuine issue of material fact, the judge found the nonmovant's proposed inferences "implausible."95 One commentator has argued that "the opinion in Matsushita appears to be crafted not by a judge searching for an issue of fact for trial, but by a panel of fact finders trying to determine a verdict." 96 In these opinions, the Supreme Court effectively reduced the courts' traditional reliance upon and deference to the common sense exercised by representatives "of the people" on civil juries.

Not surprisingly, a study recently conducted by Professor Marc Galanter reveals a marked decline in jury trials and an increase in disposition by summary judgment. While $5.5 \%$ of all civil

86 Arthur R. Miller, The Pretrial Rush to Judgment: Are the "Litigation Explosion," "Liability Crisis," and Efficiency Cliches Eroding Our Day in Court and Jury Trial Commitments?, 78 N.Y.U. L. REV. 982, 1036 (2003).

87 Id.

88 See Adam Liptak, U.S. Suits Multiply, but Fewer Ever Get to Trial, Study Says, N.Y. TIMES, Dec. 14, 2003, $\S 1$ at 1 (reporting that the raw number of civil trials in federal courts "peaked in 1985 at 12,529" and that "[I]ast year, 4,569 civil cases were tried in federal court").

89 Celotex Corp. v. Catrett, 477 U.S. 317, 323-24 (1986).

90 See id. at 325.

91 Samuel Issacharoff \& George Loewenstein, Second Thoughts About Summary Judgment, 100 YALE L. J. 73, 93 (1990).

92477 U.S. 242 (1986).

93 Id. at 248.

94475 U.S. 574 (1986).

95 Id. at 587.

96 Brian L. Weakland, Summary Judgment in Federal Practice: Super Motion v. Classic Model of Epistemic Coherence, 94 Dick. L. REv. 25, 35 (1989). 
cases in federal court went to a jury trial in 1962, that percentage had become a mere $1.2 \%$ by $2002 .{ }^{97}$ Simultaneously, it appears that disposition by summary judgment has grown-from $3.7 \%$ in 1975 to $7.7 \%$ in $2000 .{ }^{98}$ Though summary judgment still involves decision-making by a judge-not a delegate or adjunct-the marginalization of the civil jury offers additional evidence of the courts' increasing disengagement of adjudication from democratic governance and accountability to common citizens.

\section{Summary}

A few observations are now in order. First, as the courts have approved the delegation of adjudication to administrative judges and arbitrators, they have permitted state-sanctioned decisionmaking to migrate from a public and impartial body to third parties often selected by one of the disputing parties-usually the institutional, repeat players with greater economic strength. ${ }^{99}$ Second, as

97 See Marc Galanter, The Vanishing Trial: An Examination of Trials and Related Matters in Federal and State Courts 2 (Preliminary Version Oct. 24, 2003) (prepared for the Symposium on the Vanishing Trial sponsored by the Litigation Section of the American Bar Association, San Francisco, CA, Dec. 12-14, 2003). While the number of lawsuits filed in federal court increased by more than $500 \%$ during the period from 1962 to 2002, the number of trials (whether jury trial or bench trial) actually declined. This result is due to both the smaller percentage of cases going to jury trials and an even more dramatic reduction in the number of lawsuits being decided through bench trials. In $1962,6 \%$ of all civil cases were tried to a judge. By 2002 , only $.6 \%$ were decided in a bench trial. See id.

98 See id. at 34. See also Liptak, supra note 88, quoting Gillian Hadfield, University of Southern California. (observing that non-trial adjudication went from $32 \%$ of all civil cases in 1970 to $50 \%$ in 2002 ).

99 Recently, Cullen Murphy has used multiple examples of the "outsourcing" of traditionally governmental functions (e.g., school systems, security, military, mail service, airports, prisons, hospitals) to draw provocative parallels between the organization of societies in the Middle Ages and today. Murphy observes:

[T] he historian F. L. Ganshof discerned in feudal society "a dispersal of political authority amongst a hierarchy of persons who exercise in their own interest powers normally attributed to the State." In the West the path away from the Middle Ages was marked by the evolution of governments and nation-states with a sense of responsibility for the public interest rather than merely private interests. Power was no longer a form of property. Social services and protections became a consequence of citizenship, not a private deal between a lord and his vassals, or between a private entity and its clients. . . But at some point in the late twentieth century evolution's arrow began changing direction-toward the reprivatization of everything. . What some might call the New Feudalism, sociologists call the "externalization of state functions." Whatever one calls it, the phenomenon is accelerating.

Feudal Gestures: Why the Middle Ages Are Something We Can Still Look Forward To, AtLanTiC MonThly, Oct. 2003 (Vol. 292, Issue 3), at 136-37. 
the courts have come to rely on these adjuncts, they have facilitated a shift from decision-makers whose legitimacy rests in being representatives of a democratic people to those who are more likely to espouse the legal/technical norms preferred by the institutional parties. To a lesser, but nonetheless significant degree, the courts are affecting a similar shift as they abandon reliance on civil juries and instead dispose of cases based on sterile "paper trial[s] on the merits." 100 Ultimately, though perhaps unconsciously, the courts seem to be distancing state-sanctioned decision-making from the messiness of democracy and placing greater faith in the predictability and efficiency of decision-making by organizational technocrats.

\section{The Current Place of Mediation in the Evolution of THE Judicial System}

Within the last decade, another dispute resolution process-mediation-has become the "darling" 101 of the courts. Court-connected mediation programs began to appear in the 1980's and, at this point, can be found in nearly all state and federal courts. Magistrate Judge Wayne Brazil has urged that the process "democratized our institution [the courts] in potentially profound ways because mediation permitted, in fact actively encouraged, the parties to decide for themselves which values were most important to them, then to use ADR to pursue those values." 102 Has the rise of mediation "democratized" the courts, potentially reversing the trend described thus far in this Article? The answer to this question depends upon one's view of the implementation of court-connected mediation. As is so often the case, the devil is in the details.

There can be little doubt that the "contemporary mediation movement" 103 of the late 1970's and early 1980's was inspired by the principles of democracy. Mediation proponents emphasized the central role to be played by citizens in disputes. ${ }^{104}$ Citizensnot judges or attorneys or other professionals-would communicate

\footnotetext{
100 Anderson v. Liberty Lobby, 477 U.S. 242 at 266-67 (1986).

101 Lela Love, Justice in Mediation Symposium, Benjamin N. Cardozo School of Law (Mar. 12, 2004) (author's recollection of speaker's remarks).

102 Brazil, supra note 3, at 110.

103 Robert A. Baruch Bush \& Joseph P. Folger, The Promise of Mediation 1 (1994).

104 See generally Deborah R. Hensler, Our Courts, Ourselves: How the Alternative Dispute Resolution is Re-Shaping Our Legal System, 108 PenN. St. L. Rev. 165 (2003).
} 
and negotiate directly with each other, identify the issues to be discussed, determine the substantive norms that were legitimate and relevant (including the pursuit of harmony and reconciliation if they wished), ${ }^{105}$ create the options for settlement, and control the final decision regarding whether or not to settle and on what terms. ${ }^{106}$ The mediator's role was to facilitate and to help these disputing parties find their own voices and solutions. Ultimately, mediation "seemed to embody both a faith in the dignity and autonomy of individual citizens and a skepticism regarding the legitimacy of government authorities and professionals."107

Certainly, there are ways in which court-connected mediation has stayed true to this democratic spirit. Consistent with the values of self-determination and accountability, there is no binding outcome in mediation unless the parties agree to it. Attorneys, who generally attend these mediation sessions, report that their understanding of their clients' goals and potential solutions are influenced by the clients' presence. ${ }^{108}$ No doubt, some mediation sessions result in creative resolutions that reflect the particular needs, abilities, and preferences of parties. Court-connected mediation also offers citizens at least some degree of participation. At most mediation sessions, the parties attend and contribute to the discussion either directly or through their attorneys. The parties thus are not forced to rely blindly on their attorneys to conduct separate, bilateral settlement negotiations. ${ }^{109}$

But substantial data also suggests that mediation is not infusing the courts with a new manifestation of democracy. Instead, as the courts have come to rely on mediators as the next set of judging

105 See Sternlight, supra note 26 , at $\mathrm{n} .70$.

106 See Nancy A. Welsh, The Thinning Vision of Self-Determination in Court-Connected Mediation: The Inevitable Price of Institutionalization?, 6 Harv. NeGot. L. Rev. 1, 4 (2001).

107 Nancy A. Welsh, Stepping Back Through the Looking Glass: Real Conversations with Real Disputants About Institutionalized Mediation and Its Value, 19 OHIO St. J. ON DisP. RESOL. 573, 577 (2004).

108 See Julie Macfarlane, Culture Change? A Tale of Two Cities and Mandatory CourtConnected Mediation, 2002 J. Disp. Resol. 241, 309-13 (2002) (urging that court-connected mediation has resulted in "some convergence between the structure and actions of mediation and traditional litigation").

109 Research suggests that because they can attend, and thus, can at least observe that their stories are being told and considered in an even-handed and dignified proceeding, parties are more likely to conclude that their mediation session was procedurally just. See Welsh, supra note 7, at 838-39. 
adjuncts, ${ }^{110}$ the mediation process and the roles of both mediators and parties have changed. When parties failed to make significant voluntary use of mediation, courts made the process mandatory. ${ }^{111}$ Thus, citizens lost the ability to decide for themselves whether or not to try mediation. As attorneys have become more frequent participants in mediation sessions and have assumed responsibility for selecting mediators, the process has become less focused on empowering citizens and more focused on forcing these citizens to confront and become reconciled to the legal, bargaining and transactional norms of the courthouse..$^{112}$. Attorneys select fellow attorneys as mediators and especially value those who possess substantive expertise and the ability to value cases and conduct "reality testing" with the parties. ${ }^{113}$ Many of these mediators maximize their own influence by minimizing the time spent by the parties in joint session. These mediators quickly separate the parties

110 Mediators may be considered "judging adjuncts," as the role of the judge has expanded to include settlement. See Resnick, supra note 19, at 654, n. 206 (noting and demonstrating some judges' enthusiasm for mediators and arbitrators).

111 See Welsh, supra note 106, at 24-25 (describing the adoption of mandatory mediation programs).

112 See Ellen Waldman, Identifying the Role of Social Norms in Mediation: A Multiple Model Approach, 48 Hastings L. J. 703, 723-57 (1997) (describing the "norm-educating" and "norm-advocating" models of mediation that are more common in mediation programs located within institutions that have norm-enforcing mandates).

113 See James J. Alfini, Trashing, Bashing, and Hashing It Out: Is This the End of "Good Mediation?," 19 FLA. ST. U. L. Rev. 47, 66-71 (1991) (describing new techniques brought into mediation because of the use of legal professionals as mediators); Elizabeth Ellen Gordon, Why Attorneys Support Mandatory Mediation, 82 Judicature 224, 228 (1999) (noting that attorneys prefer mediators who are experienced trial lawyers); Barbara McAdoo, A Report to the Minnesota Supreme Court: The Impact of Rule 114 on Civil Litigation Practice in Minnesota, 25 Hamline L. Rev. 401, 429-30 (2002) (reporting that attorneys place highest value on mediators' ability to value cases and experience as litigators); Barbara McAdoo \& Art Hinshaw, The Challenge of Institutionalizing Alternative Dispute Resolution: Attorney Perspectives on the Effect of Rule 17 on Civil Litigation in Missouri, 67 Mo. L. Rev. 473, 524 (2002) (reporting that lawyers choose mediation to save litigation expenses, speed settlement, provide needed reality check for opposing counsel and clients, make settlement more likely, and help everyone value the case); Barbara McAdoo \& Nancy A. Welsh, Does ADR Really Have a Place on the Lawyer's Philosophical Map? 18 Hamline J. Pub. L. \& Pol'Y 376 (1997) (reporting that the majority of Hennepin County lawyers interviewed wanted mediators to give their view of settlement ranges); Thomas Metzloff et al., Empirical Perspectives on Mediation and Malpractice, 60 LAW \& CONTEMP. ProBs. 107, 144-45 (1997) (reporting that almost $70 \%$ of attorneys want mediators to provide opinions on the merits of cases and that attorneys highly value the mediator's substantive expertise); Roselle Wissler, An Evaluation of the Common Pleas Court Civil Pilot Mediation Project, ix (2000) (unpublished manuscript, on file with author) (reporting that "[a]ttorneys had more favorable assessments of the [mediation] process and the mediator and analyzed mediation as more helpful in achieving case objectives if the mediator evaluated the merits of the case and suggested settlement options"). 
and become their sole channel of communication and negotiation, shuttling back and forth with the information and descriptions of offers and counter-offers that will facilitate settlement. ${ }^{114}$ Attorneys also now dominate the discussion and negotiation in mediation sessions. ${ }^{115}$ Indeed, in many personal injury and medical malpractice cases, the defendants are not expected to attend mediation sessions, ${ }^{116}$ and in some courts, parties generally are discouraged from attending. ${ }^{117}$ These changes in the implementation of mediation, though often understandable, generally have the effect of constricting, not celebrating, citizens' ability to engage in selfgovernance and demand accountability from the mediators, the mediation process and mediated outcomes. ${ }^{118}$ In sum, court-con-

114 See Welsh, Making Deals, supra note 7, at 809-13 (describing the marginalization of joint session and rise of caucus in court-connected mediation); Welsh, Stepping Back Through the Looking Glass supra note 107, at 669-71 (describing disputants' reactions to caucus which relate to perceptions of procedural justice); Ian Ayres \& Barry J. Nalebuff, Common Knowledge as a Barrier to Negotiation, 44 UCLA L. REv. 1631, 1633-34 (1997) (describing the strategic use of caucus to avoid the communication of higher-order information).

115 See, e.g., Elizabeth Ellen Gordon, Attorneys' Negotiation Strategies in Mediation: Business as Usual?, Mediation Q., Vol. 17, No. 4, 377, 383 (2000). "[A]ttorneys rather than disputants are unquestionably the main negotiators in mediated settlement conferences." Id. See also Gordon, supra note 113, at 227 (reporting that in observed mediations, lawyers dominated negotiation, the minority of clients who did "play active roles" were "supporting rather than starring players," and that three-quarters of responding attorneys disagreed with the statement, "Litigants should be the most active participants in mediation, with attorneys standing by to offer legal advice."); Metzloff et al., supra note 113, at 123-25 (discussing the limited involvement of plaintiffs and defendants during medical malpractice mediation sessions). But see McAdoo, supra note 113, at 408 (reporting that nearly eighty percent of attorneys perceive that mediators always or frequently encourage clients to participate in the mediation process).

116 See Metzloff et al., supra note 113, at 123-25. See also Kimberlee K. Kovach \& Lela P. Love, Mapping Mediation: The Risk of Riskin's Grid, 3 Harv. NeGot. L. Rev. 71, 99 (1998) (reporting that the Civil Appeals Management Plan of the United States Court of Appeals for the Second Circuit "neither expects nor requires party participation, though mediators may invite the parties to attend the conference").

117 This is the case, for example, in the mediation program established by the Pennsylvania Commonwealth Court. The order establishing the program provides that, "[a]ll mediation sessions must be attended by counsel for each party with authority to settle the matter, and, if required, such other person with actual authority to negotiate a settlement." While the order also provides that " $[t]$ he mediation judge may at his or her discretion require the parties (or real parties in interest) to attend mediation," it has not been the practice of the mediation judge to require the clients to attend. It is usually the case that clients do not attend the mediation session. The clients that do arrive at the mediation session with their attorneys generally are not included in most of the negotiation that occurs in the session. Telephone Interview with John Gordon, Program Director, Pennsylvania Commonwealth Court Mediation Program (Feb. 28, 2001).

118 See Reuben, Dispute Resolution and Democracy, supra note 10 (suggesting several criteria-including autonomy, participation and accountability-that should be used to ex- 
nected mediation has evolved from a process that focused on enhancing individual citizens' voice, control and assurance of accountability into a mechanism that resolves cases by reconciling these citizens to the institutional reality (or at least mediators' and attorneys' perception of the reality) of the courts and litigation. ${ }^{119}$

In addition, and consistent with the courts' minimal oversight of administrative law judges and arbitrators, most courts do very little to assure the accountability of the mediation process, individual mediators, or mediated outcomes. ${ }^{120}$ The mediators on many courts' rosters are private providers who are selected by attorneys and paid by the parties, not the courts. This structure permits court-connected mediation programs to operate quite self-sufficiently and, from the courts' perspective, quite cost-effectively. Indeed, in many states, mediation is now a business, with a small group of insurers as repeat players and a select group of mediators handling a large number of the cases. Though courts generally require mediation skills training in order to qualify for service on a roster of court-connected mediators, few courts have designated a staff member to monitor the mediators' performance, regularly observe mediation sessions, or gather and evaluate feedback from parties and attorneys. Unfortunately, some court-connected mediators have even welcomed the cessation of evaluation efforts

amine the relationship between democracy and arbitration); Robert Ackerman, The Administrative Process as a Response to Tragedy: The September 11 Victim Compensation Fund (forthcoming, on file with author) (discussing accountability in the context of the September 11 Victim Compensation Fund).

119 See Marc Galanter, The Emergence of the Judge as a Mediator in Civil Justice, 69 JuDiCATURE 257 (describing the evolution of judicial enthusiasm for settlement). As long ago as 1947, one judge observed:

Pre-trial seems to have developed a method of disposing of controversies, within the court, with the aid of lawyers, but without the delay, expense and technicality that have cursed the judicial process for years. It eliminates appeals. It commends itself to businessmen as a sensible and practicable procedure. It provides a method by which disputes can be disposed of in a way that leaves all parties satisfied instead of one or both disgruntled and with a grievance against courts and the law. It should increase the use of the courts.

Id. at 259, quoting Harry D. Nims, Pretrial in the United States, 25 CAN. B. Rev. 697, 717-18 (1947). See also Resnik, supra note 20, at $933-49$ (arguing that federal courts have embraced settlement as a result of changes in their dockets, promotion of settlement in judicial training, and the federal courts' increasing sense of themselves as a corporate, business-like body with its own institutional needs and agenda).

120 See Barbara McAdoo \& Nancy A. Welsh, General Civil ADR in ADR HANDBOoK FOR JUDGES (forthcoming, on file with author) (describing the relationship between courts and court-connected mediators, including selection requirements, payment, quality assurance and discipline). 
as a signal of the courts' confidence in them. ${ }^{121}$ As Magistrate Judge Brazil has observed, courts' financial constraints must be acknowledged as real and must be confronted "squarely." 122 But, as Brazil has also warned, the temptation to "cut administrative corners and sometimes. . . take great risks with quality control. . . could jeopardize public confidence not only in ADR, but also in the courts themselves." 123 Such public confidence and accountability are essential in a democracy.

Courts might also exercise quality control by carefully scrutinizing mediated settlement agreements, particularly when one of the parties objects to enforcement of the agreement or seeks to set it aside. Increasingly, courts are hearing these sorts of arguments, often accompanied by allegations that mediators engaged in coercive and/or biased behaviors. ${ }^{124}$ Courts, however, are rarely sympathetic to these parties who seek to undo settlement agreements. Mediators' evaluative interventions, even when they are quite aggressive, are unlikely to qualify as "coercive enough" to merit returning cases to the courts' trial dockets. ${ }^{125}$ Indeed, some courts seem to view unhappy parties' attempts to undo their mediated settlement agreements as nothing less than an affront to the judicial system itself. ${ }^{126}$

Thus, courts' delegation of the settlement function to mediators is marred by the same coupling of deference and lack of real accountability that characterizes the courts' delegation of adjudicative functions to administrative and arbitral forums.

\section{Returning to Mediation's Promise as a Means to Reinvigorate a Democratic Justice System}

In general, the courts' current zeal for delegation combined with the lack of meaningful accountability mechanisms threatens to undermine the courts' entitlement to respect as democratic institutions doing their best to deliver justice. Focusing on court-connected ADR programs, Magistrate Judge Wayne Brazil has warned

\footnotetext{
121 See Joseph Folger et al., A Benchmarking Study of Family, Civil and Citizen Dispute Mediation Programs in Florida 94 (2001).

122 Brazil, supra note 3 , at 128.

123 Id. at 118.

124 See Welsh, supra note 106, at 9-12.

125 See id. at 74-78.

126 See Welsh, supra note 106, at 14.
} 
about the consequences of a single-minded focus on the achievement of efficient resolution:

[T] hose who would insist on using only efficiency criteria to assess the value of ADR programs jeopardize the courts' most precious and only necessary assets: public confidence in the integrity of the processes the courts sponsor and public faith in the motives that underlie the courts' actions. We must take great care not to make program design decisions that invite parties to infer that the courts care less about doing justice and offering valued service than about looking out for themselves as institutions (e.g., by reducing their workload, or off-loading kinds of cases that are especially taxing or emotionally difficult or that are deemed "unimportant."). ${ }^{127}$

Thus far, this Article has examined the large-scale "program design decisions" that present a cumulative threat to the trust that a democratic people can and should place in those entrusted with delivering the justice that will be enforced by the state. The remainder of the Article will consider the program design decisions that can and should be made in order to reassure citizens that the courts and their adjuncts-at least mediators as settlement adjuncts-remain accountable to "the people" and thus can be trusted to deliver justice. ${ }^{128}$

The first program design choice actually involves ADR advocates more than it does courts. In the last couple of decades, mediators and mediation advocates have done their share of bashing the courts and the public justice system, as part of a strategy to justify replacing judges with someone or something else. But the common good of a democratic nation benefits from the existence of a sufficiently-supported and accountable public justice system. Mediation advocates need to help our courts overcome their current problems and regain an appropriate measure of self-respect for their unique role in enabling a democratic people to govern themselves. This means, of course, becoming advocates for sufficient funding for courts, the appointment of sufficient numbers of judges and the protection of judges' independence from inappropriate economic or political influence. ADR experts who have traveled to other countries to teach or consult regarding ADR have realized that healthy ADR programs require healthy judicial

127 Brazil, supra note 3, at 124.

128 See McAdoo \& Welsh, supra note 120 (proposing several reforms, some of which are included here). 
systems. ${ }^{129}$ The same mutually symbiotic relationship should exist in the United States.

The second program design choice is likely to appear painful, but may be less so than it first seems. Courts should end their reliance on mandatory mediation. ${ }^{130}$ The courts are lending their legitimacy to mediation in requiring its use. The combination of mandatory programs and a lack of significant accountability measures, however, invite abuse and a potential deterioration of the courts' legitimacy. If mediation is truly a valuable process that responds to citizens' desires for an alternative means to resolve disputes, the process should be able to stand on its own, freely selected by parties as their disputes arise. At the very least, the courts' authority to mandate mediation should sunset within two to three years after a court-connected mediation program has been introduced. During this initial phase, attorneys will become educated about the process. ${ }^{131}$ Research indicates that once attorneys use mediation, they become advocates for its future use. If attorneys have not become advocates, there is probably something wrong with the program, and it deserves to end.

Finally, and especially while the use of mediation is mandatory or strongly encouraged by judges, the courts should view mediators as their agents-and provide for meaningful oversight that assures just resolution. ${ }^{132}$ Courts can accomplish such oversight by establishing expectations beyond settlement for their mediators. The procedural justice literature provides a rich set of measures of those behaviors that are likely to be perceived as just. ${ }^{133}$ Courts also should assign staff to monitor mediators' performance through periodic observations, distribution and assessment of meaningful post-mediation surveys and interviewing of attorneys and parties.

129 See Carrie Menkel-Meadow, Correspondence and Contradictions in International and Domestic Conflict Resolution: Lessons from General Theory and Varied Contexts, 2003 J. DisP. RESOL. 319 n. 104 (urging that the "absence of a legitimate and trusted legal system prevents full assimilation and acceptance of a supplementary set of institutions to offer different forms of conflict resolution" but noting that others argue otherwise).

130 See generally Hensler, supra note 104, at 165.

131 See Welsh, supra note 106, at 24.

132 The Code of Conduct for United States Judges, particularly Canon 3, should also be revised to make it clear that judges have an obligation to oversee those to whom they have delegated the settlement function. See Canon 3, "A Judge Should Perform the Duties of the Office impartially and Diligently," available at http://www.uscourts.gov/guide/vol2/ch1. html\#3 (last visited Apr. 4, 2004).

133 See Welsh, supra note 7, at 817-26. 
Such monitoring exists in good court-connected programs. It should be common in all programs. ${ }^{134}$

Though procedural justice often results in perceptions of substantive justice, courts also need to do more to ensure that mediated outcomes are fair according to some principled set of norms. One alternative is to require courts to review and approve mediated settlement agreements. Obviously, this option presents difficulties for an already-overloaded system and is likely to result in replication of the deferential standards of review that afflict other contexts. Alternatively, courts could provide a short cooling-off period for mediated settlement agreements, during which the parties themselves could evaluate the fairness of the outcome-using whatever norms they deem legitimate-and choose to accept or rescind their agreements without penalty. Such cooling-off periods are relatively common in divorce and child custody mediation and are relatively straightforward mechanisms to ensure that parties perceive their agreements as sufficiently just. From the courts' perspective, the adoption of cooling-off periods for mediated agreements would signal mediators' ultimate accountability to the citizens involved in this court-connected process. A cooling-off period would reward productive mediator behaviors that build parties' commitment to and investment in their agreements and create a negative consequence for those mediators who employ aggressive tactics that endanger courts' legitimacy as the domain in which citizens will experience justice. ${ }^{135}$

\section{CONCLUSION}

The judicial system of the United States seems to be changing, and mediation is playing one small part in that change. Yet, change should be tempered by context, and even as the judicial system changes, it should reflect the values of our democracy. Our courts draw their legitimacy from their accountability to, and the responding support of, a democratic people. Within the context of democracy, judicial adjuncts exercising public functions must also be held

134 See Sharon Press, Building and Maintaining a Statewide Mediation Program: A View from the Field, $81 \mathrm{KY}$. L. J. 1029, 1030 (1993) ("[M]erely providing the statutory mechanism for sending cases to mediation, without creating a central office to assist the oversight of the program, may be an inappropriate delegation of court authority and result in an inadequate method of overseeing the provision of justice.").

135 See Welsh, supra note 106, at 91-92. 


\section{CARDOZO J. OF CONFLICT RESOLUTION [Vol. 5:117}

accountable for the justice of their decision-making procedures and outcomes.

Perhaps mediation, which has so far played a relatively small role in the judicial system's larger evolution, can play a much more significant part in helping the courts reconcile the need for delegation (or more pejoratively, "outsourcing") and accountability. Mediation may then become an important complement that helps the courts play their appropriate role in the lives of the citizens in a democratic nation. 